\title{
REVOCATION OF RE-ELECTED RIGHTS FOR CORRUPTOR IN PUBLIC OFFICES WITHOUT TIME LIMITATION THE PROGRESSIVE LAW PERSPECTIVE
}

\author{
FIRA MUBAYYINAH \\ STAI AL Hikmah Tuban, Jawa Timur \\ Email: firamubayyinah@gmail.com \\ DOI: http://dx.doi.org/10.24952/fitrah.v5i2.2196
}

\begin{abstract}
Abstrak
Permasalah korupsi selalu menjadi pembahasan publik, tidak hanya karena akibat yang ditimbulkannya. Namun juga karena pelakupelaku korupsi yang tertangkap mereka adalah berasal dari partai politik. Dan cenderung setelah mereka menjalani masa pidana, kembali masuk pada area pemegang kebijakan atau kewenangan melalui jalur politik kembali. Penjatuhan pidana tambahan pencabutan hak politik bagi korutor tercantum dalam Putusan Mahkamah Agung Nomor: 537k/Pid.Sus/2014, dan Nomor 1195K/Pid.Sus/2014. Penerapannya tidak dibatasi jangka waktu seperti diatur dalam pasal 38 KUHP. Pencabutan hak politik disatu sisi dianggap bertentangan dengan HAM, namun pencabutan hak politik menjadi hukuman yang penting diberlakukan, mengingat pelaku korupsi tidak sedikit berasal dari partai politik. Penerapan pidana merupakan sarana penal guna mencegah terjadinya tindak pidana. Pencabutan hak politik yang masih diperdebatkan dapat berdampak pada pelaksanaannya. Oleh karena dalam pelaksanaannyya tentu membutuhkan Aparat Penegak Hukum yang memiliki langkah pemikiran dan langkah progresif. Penjatuhan pidana merupakan kewenangan Hakim. Hakim dalam menjatuhkan pidana hendaknya bersandar pada prinsip keadilan substantive dan ditujukan untuk memberikan perlindungan kepada masyarakat (social deffence).
\end{abstract}

Kata Kunci: Korupsi, Koruptor, Hak Politik

\begin{abstract}
The problem of corruption has always been a public discussion, not only because of its consequences. But also because the perpetrators of corruption that they caught were from political parties. And it tends to be after they go through the criminal period, re-enter the area of policy holders or authority through political channels again. Additional criminal imposition of revocation of political rights for the corutor is stated in the Decision of the Supreme Court Number: 537k / Pid.Sus / 2014, and Number 1195K / Pid.Sus / 2014. The application is not
\end{abstract}


limited to the period as stipulated in article 38 of the Criminal Code. Revocation of political rights on the one hand is considered contrary to human rights, but revocation of political rights becomes an important punishment imposed, considering that the perpetrators of corruption do not come from political parties. The application of criminal acts is a means of reason to prevent criminal acts. Revocation of political rights which is still debated can have an impact on its implementation. Therefore, in its implementation, of course requires a Law Enforcement Officer who has a step of thinking and progressive steps. Penal punishment is the authority of the Judge. Judges in imposing crimes should rely on the principle of substantive justice and are intended to provide protection to society (social deffence).

Keywords: Corruption, Corruptor, Political Rights.

\section{INTRODUCTION}

Corruption is one of the crimes considered as a common enemy by the international community, including Indonesia, which includes criminal acts of corruption which is categorized as a serious crime that needs extraordinary efforts to handle it.

Based on data from the Corruption Eradication Commission (KPK) of the Republic of Indonesia (KPK), the information was obtained that the Corruption Eradication Commission netted hundreds of corruptor from House of representative. From the data obtained it was stated that the people who were processed by law were from the House of Representatives (DPR) and Regional Legislative Council (DPRD). There are a total of 220 people, consisting of 74 from the member of House of Representatives and 146 from the members of Regional Representatives Council ${ }^{1}$, with the following data:

The total number of Regional Representatives Council members who have been investigated by KPK 146 people were ensnared from the beginning of the Corruption Eradication Commission established until September 2018, with the following details:
1. Bengkulu
: 4 people
2. DKI Jakarta
: 1 person
3. Jambi
$: 1$ person

${ }^{1}$ Dhani Irawan, “Sejak KPK Berdiri, Ada 220 Wakil Rakyat Korup Dijerat," Web Blog, detiknews, 18 September 2018, https://news.detik.com/berita/d-4216860/sejak-kpk-berdiri-ada-220wakil-rakyat-korup-dijerat. 
4. West Java : 5 people

5. Central Java $\quad: 5$ people

6. East Java : 47 people

7. South Kalimantan : 2 people

8. East Kalimantan $: 1$ person

9. Lampung :3 people

10. North Maluku $\quad: 1$ person

11. Riau : 13 people

12. South Sumatra : 13 people

13. North Sumatra : 50 people

As for the DPR members, a total of 74 people were ensnared from the beginning of the KPK established until September 2018. Following are the data:
1. 2007
: 2 people
2. 2008
: 6 people
3. 2009
: 8 people
4. 2010
: 27 people
5. 2011
: 3 people
6. 2012
: 5 people
7. 2013
: 3 people
8. 2014
: 2 people
9. 2015
: 4 people
10. 2016
: 5 people
11. 2017
: 6 people

12. 2018 (until September): 3 people

Many of the corruptors who are public officials are subject to criminal sanctions and then they are convicted status, but then rise again and exist in the world (both state and public positions) to get a position or in some cases it was found that a suspect and a convict are still trying to exist in executive positions \& state administrators such as; Azirwan (convicted of bribery against members of the Corruption Eradication Commission of Republic Indonesia Al-Amin Nasution who later became the Head of Maritime Affairs \& Fisheries of the Riau Islands Province), several former members of the Provincial Representatives of West Papua including: Jimmi Damianus Idjie, Chaidir Jafar, Robert Riwu et al (all of whom were members of the West Papua Regional Legislative Council for the period of 2009 - 2014 were convicted of corruption in the 2011 West Papua 
FITRAH Jurnal Kajian Ilmu-ilmu Keislaman

Vol. 05 No. 2 Desember 2019

Regional Budget misuse amounting to Rp. 22 billion), Teddy Tengko (Regent of Aru Islands Regency related to Convicted District Court) State budget (APBD) Corruption from North Maluku, which is still determined to take office), which was finally able to make the state's efforts to eradicate corruption contradictory because in the administration of government and the state upholds ethics, morals and honesty in its activities based on the Pancasila \& the 1945 Constitution 2 . Vonnie Anneke Panambung while serving as the North Minahasa Regent, he was entangled in a corruption case together with the Regent of Kutai Kartanegara HR Syaukani and was sentenced to 1.5 years in prison in 2008 and in the corruption case was not accompanied by revocation of his right to be elected to be a public officer so that in 2015 he again participated in the legislative election and was reelected as North Minahasa Regent until now.

Anti-corruption activists and the public question about the appropriateness of ex-convicts of corruption in political election, considering that from an ethical point of view, corruption must be ethically condemned for two reasons: First, every rupiah that is corruptly obtained is stolen money. Every corruptor is a thief. Second, corruption is a high level of injustice, because it occurs by utilizing a special position that no one else has. As a result, corruption keeps poor people out of poverty. Corruption is one of the biggest cheats in the life of the nation. Because of corruption, little people cannot live humanely. Because the costs of stealth are weighing on our industry, our workers cannot be paid fairly, this not only means cheating the little people, but also makes unsuccessful attempts at creating qualified jobs and products. ${ }^{3}$

The Republic of Indonesia General Election Commission (KPU) has received a growing aspiration in the community of former corruption convicts who wish to advance to the electoral contestation by issuing Regulation of the Republic of Indonesia General Election Commission Number 20 of 2018 concerning Nominations for Members of the House of Representatives, Provincial Representatives and Regional Representatives Council who prohibit ex-convicts of corruption from becoming legislative candidates and also the Election Commission Regulation of the Republic of Indonesia Number 14 of 2018

2 Dikutip dari Memori Banding dari Jaksa Penuntut Umum dalam perkara atas nama Terdakwa Anas Urbaningrum, Tahun 2014

${ }^{3}$ Franz Magnis-Suseno, Korupsi Mengorupsi Indonesia: Catatan tentang Korupsi dari Sudut Etika, dikutip dalam bukunya Wijayanto \& Ridwan Zachrie, Korupsi Mengorupsi Indonesia, Sebab Akibat dan Prospek Pemberantasan, PT. Gramedia Pustaka Utama, 2009, hlm. 788 
concerning the Nomination of Individual Participants in the Election of Members of the Regional Representative Council in article 60 paragraph (1) letter "j" which organize about ex-convicts of corruption, but this provision has been opposed by ex-corruption convicts who are candidates for the member of House of Representatives of Republic Indonesia and Regional Representatives Council candidates namely Sarjan Tahir, House of Representatives of Republic Indonesia candidates from South Sumatra; Darmawati Dareho will be the legislative candidate for Regional Representatives Council of the North Sulawesi; Patrice Rio Capella, future House of Representatives of Republic Indonesia candidate from Bangka Belitung Province; and Al Amin Nur Nasution, prospective candidates from Jambi Province ${ }^{4}$, by conducting a judicial review of the General Election Commission regulations to the Indonesian Supreme Court and on September 13, 2018 the Supreme Court through its ruling Number 46 P / HUM / 2018 and Number 30 P / HUM / 2018 decided to grant the application of the judicial review so that candidates for legislative members and / or government institutions that had been convicted of corruption within the 5 years prior to the registration could still nominate themselves or be elected as members of the legislative and / or government institutions.

The law enforcers have taken many actions against the perpetrators of corruption, to impose additional crimes in the form of revocation of political rights. The Corruption Eradication Commission through its spokesman Febri Diansyah, said, during 2013-2017, the corruption court (tipikor) had revoked the political rights of 26 corruptors who were proven to be involved in corruption cases. "There are 26 people who serve as chairmen and administrators of political parties, members of the house of Representatives and Provincial and Regional Representatives Council, regional heads and other positions that have great public risk if they become political leaders," said Febri in his written statement, Tuesday (09/18/2018). He explained, the revocation of corrupt political rights needs to be done in order to reduce the potential for corrupt practices in the future. According to Febri, the revocation of new political rights was initiated by the Corruption Eradication Commission in the previous leadership period. "Because after the discussion and analysis at the current Corruption Eradication

\footnotetext{
${ }^{4}$ Amirullah, "4 Eks Napi Korupsi Gugat Peraturan KPU Ke Mahkamah Agung," Web Blog, Tempo, 2018, https://nasional.tempo.co/read/1105127/4-eks-napi-korupsi-gugat-peraturankpu-ke-mahkamah-agung.
} 
Commission, there is a big risk for the public if the convicted in certain cases serves as political leader," he said. Febri explained, the Corruption Eradication Commission has the authority to submit demands in the form of revocation of political rights against politicians who are entangled in corruption cases. ${ }^{5}$

All agreed that public officials who were convicted of corruption must be punished severely and banned from holding public office. Additional crimes in the form of revocation of the right to be re-elected for regional heads or representatives of the people proven to be corrupt in the Regional Head Election are appropriate and need to be done so that there is a deterrent effect for corruptors and it is hoped that the community will have leaders and representatives with integrity and prioritize the public interest. However, in several decisions there were decisions that revoked political rights among judges that were not the same, namely there were limitations on the revocation of time that varied between 2 (two) years to 5 (five) years, and there were several decisions that did not include a time limit on the revocation of political rights for elected in a public office or in other words the right is forever revoked, as follows:

1. Decision of the Supreme Court of the Republic of Indonesia Number $537 \mathrm{~K} /$ Pid.Sus/2014 dated June 4, 2014 an. Defendant Inspector General of Police Drs. Djoko Susilo, SH., M.Sc; who decided: Punish the Defendant with additional crimes in the form of revocation of certain rights to vote and be elected in public office.

2. Decision of the Supreme Court of the Republic of Indonesia Number: 1195 K/ Pid.Sus / 2014 dated 15 September 2014 an. The Defendant Lutfi Hasan Ishaaq decided: Revoke the Defendant's right to be elected in a public office.

3. Decision of the Supreme Court of the Republic of Indonesia Number: 1648 K/ Pid.Sus / 2014 dated 17 November 2014 an. Defendant H.M. Rusli Zainal who decided: Determined to revoke the defendant's right to be elected in public office.

4. Decision of the Supreme Court of the Republic of Indonesia Number: $285 \mathrm{~K} /$ Pid.Sus / 2015 dated February 23, 2015 an. Defendant Hj. Ratu Atut Chosiyah,

\footnotetext{
${ }^{5}$ Kompas Cyber Media, “KPK: Hak Politik 26 Koruptor Dicabut Sepanjang 2013-2017,” Web Blog, KOMPAS.com, $26 \quad$ September 2013, https://nasional.kompas.com/read/2018/09/18/13252541/kpk-hak-politik-26-koruptor-dicabutsepanjang-2013-2017.
} 
SE who decided: Determined to revoke the defendant's right to be elected in public office.

5. Decision of the Supreme Court of the Republic of Indonesia Number: $1261 \mathrm{~K} /$ Pid.Sus / 2015 dated June 8, 2015 an. Defendant Anas Urbaningrum has decided: To impose an additional sentence against Defendant Anas Urbaningrum in the form of revocation of the right to be elected in public office.

6. Decision of the Supreme Court of the Republic of Indonesia Number: $2864 \mathrm{~K} /$ Pid.sus / 2015 dated January 13, 2016 an. Defendants Ade Swara and Nurlatifah decided: Drop the criminal revocation of the rights of the defendants to be elected in public office.

\section{RESEARCH PROBLEM}

Based on the introduction above, the problems can be identified regarding the revocation of the right to be elected in a public office for perpetrators of corruption, namely:

1. How is a juridical review of the revocation of rights elected in public office?

2. How does the progressive legal theory see on the legitimacy of judges' decisions on the revocation of elected rights in public office without time limit?

\section{RESULTS AND DISCUSSION}

1. Juridical Review of Revocation of Selected Rights in a Public Position

Corruption is widely practiced by corruptors while serving as public officials including those of the Governor, Mayor/Regent, members of the the member of House of representatives of republic of Indonesia, member of Provincial Representatives and member of Regional Representatives Council who get their positions through the general election process, so it is necessary to revoke the political rights of corruption defendants to limit their access to re-occupy the position through additional criminal charges brought by the Public Prosecutor in the form of an additional criminal revocation of elected rights in a public office. Legal sanctions met with social and political sanctions are expected to make a stronger and firmer deterent effect because a corrupt public official tends to misuse the authority entrusted to him and use his position for the benefit of himself or his group. 
Revocation of political rights or the right to be elected in this public office based on the provisions of the Law of the Republic of Indonesia Number 31 of 1999 concerning Eradication of Corruption and its amendment to Law number 20 of 2001 regulates the punishment of perpetrators of corruption in addition to the main criminal sanctions in the form of prisons and fines, it can also be subject to a substitute for criminal money as stipulated in Article 17 of Law number 31 of 1999 which reads, "in addition to being convicted as referred to in Article 2, Article 3, Article 5 through Article 14, the defendant may be subject to additional penalties as referred to in Article 18. "Juncto Article 18 of Law Number 31 of 1999 which states that in addition to additional crimes as referred to in the Criminal Code Act, as additional crimes are:

a. Confiscation of tangible or intangible immovable property or immovable property used for or obtained from a criminal act of corruption, including a convict-owned company in which a criminal act of corruption is committed, as well as from goods replacing such items;

b. Payment of replacement money in the same amount as much as property obtained from criminal acts of corruption.

c. Closure of all or part of the company for a maximum period of 1 (one) year;

d. Revocation of all or part of certain rights or the abolition of all or part of certain benefits, which have been or can be given by the Government to the convicted person.

And the provisions of article 35 paragraph (1) of the Criminal Code which states: The rights of a convicted person who by the Judge's decision can be revoked in the matters specified in this law, or in other general rules are:

a. The right to hold an office in general or a certain position;

b. Right to enter the armed forces;

c. The right to vote and be elected in elections held based on general rules;

d. The right to become a Legal Counsel or administrator on the determination of a court, the right to be a guardian, supervisor, guardian or supervisor of those who are not their own children;

e. The right to exercise the power of the father, run a guardianship or ability on his own child; 
f. The right to run certain livelihoods;

And the revocation of the right to be elected in a public position is carried out restrictions based on the provisions of Article 38 of the Criminal Code, namely:

a. If revocation of rights is carried out, the judge determines the duration of revocation as follows:

1)In the case of capital punishment or life imprisonment, the length of life revocation;

2)In the case of imprisonment for a certain period or imprisonment, the duration of revocation is at least two years and at most five years longer than the principal criminal sentence;

3)In the case of criminal fines, the duration of revocation is at least two years, and a maximum of five years;

b. Revocation of rights shall take effect on the day the judge's decision can be carried out.

The limitation on the period of revocation of political rights or the right to be elected in public office is also contained in the decision of the Constitutional Court Number 4 / PUUVII / 2009 dated March 24, 2009 which in principle states that the revocation of the elected right is considered constitutional with certain conditions which are valid for a limited period of time only for 5 (five) years since the convicted person has finished his sentence. Exempt for ex-convicts who openly and honestly tells the public that he is a former convict and is not a perpetrator of recurrent crimes. So thus, the perpetrators of corruption who have served imprisonment and fines and revocation of their rights with the limitation after 5 (five) years can be re-nominated as contestants to be elected public officials such as becoming president, governor, regent / mayor, members House of Representatives, Provincial representatives and Regional Representatives Council, and others.

The revocation of rights to be elected in a public office becomes somewhat ambiguous when a Constitutional Court ruling number 42 / PUUXIII / 2015 dated 9 July 2015 basically states that Article 7 letter g of the Regional Election Law does not have binding legal force as long as it is not exempted from being excluded. For ex-convicts who openly and honestly tells the public that they are ex-convicts. Which can be interpreted as a 
decision that revoked the right to be elected in public office does not need to be applied again in the punishment because the election is left to the voters who will eliminate contestants who are former perpetrators of corruption.

Decision of the Constitutional Court number 42 / PUU-XIII / 2015 dated July 9, 2015 was decided not unanimously by all constitutional judges, but there were 3 (three) members of the constitutional judge who held dissenting opinions which basically stated the revocation of the right to be elected in office the public should be interpreted as the decision of the Constitutional Court Number 4 / PUUVII / 2009 dated March 24, 2009. Thus revocation of the right to be elected in a public position has legality and is not.

2. The Study of Progressive Legal Theory of Revocation of Elected Rights in Public Position Without Time Limits

In fact the law is maintained by the community through the operation of the law carried out by legal actors. When legal workers succeed in maintaining the law in a way that is acceptable to society, then at that time the law dominates something that is alive. The soul, spirit, and spirit of the law that is maintained by law enforcers is not only a determining factor in achieving the goals of the law, but also a determinant of the life and death of the law itself. ${ }^{6}$

Linguistically progressive law is an expression of the nature and substance of law. The term Satjipto Rahardjo capitalizes what is meant by progressive law and the paradigm that sustains it, namely first, law is for humans, not humans for law. Second, progressive law refuses to maintain the status quo in law. Maintaining the status quo means maintaining everything, and the law is the benchmark for everything. The status quo view is in line with positivistic, normative and legalistic ways, so that once a law states or formulates it like that, we cannot do much unless the law is changed first. The status quo which is maintained through the principle of legal certainty, not only freezes the law, but also has the potential to freeze

${ }^{6}$ Yudi Kristiana, Pemberantasan tindak pidana korupsi: perspektif hukum progresif (Jogjakarta: Thafa Media, 2016), hlm. 9. 
the community. ${ }^{7}$ Third, progressive law gives great attention to the role of human behavior in law. ${ }^{8}$

Considering that progressive law rests with human intervention, it is carrying the consequences of demanding creativity in law enforcement in addition to overcoming legal disadvantages. This is intended to make legal breakthroughs. This is expected to realize humanitarian goals through the operation of the law, this is what is called Stajipto Rahardjo with a law that makes happy. Thus using the law must be used consciously as a means of achieving humanitarian goals, which means it must be sensitive to social demands.

The provisions of article 38 paragraph (1) of the Indonesian Criminal Code have provided a time limit for revocation of the right to be elected through a general election which is limited to at least 2 (two) years and a maximum of 5 (five) years. The time limit in the Criminal Code does not rule out the possibility of a convicted of corruption after serving his conviction will re-occupy a public position, which should no longer be given access to that position, Vonnie Anneke Panambung is a concrete example of a ex-convict of corruption while serving as North Minahasa Regent caught in a corruption case together with Kutai Kartanegara Regent HR Syaukani was sentenced to 1.5 years in prison in 2008 and in 2015 resumed in the regional head election contest and was re-elected as North Minahasa Regent until now.

This actually hurts the sense of public justice, where to become an ordinary civil servant must state never been convicted in a criminal case, how could the leader of the employee be a former convict of corruption who ethically has a moral disability? Article 38 Paragraph (1) of the Indonesian Criminal Code should be revised and provide a maximum lifetime limit.

Airlangga Pribadi, a political observer from Airlangga University, said that the revocation of corrupt political rights did not violate human rights. Because, those who are caught corruption on average are people with positions in the executive, legislative, and judiciary. "It means they get the mandate to manage public affairs and public institutions. Now, when they abuse their authority and power, it means it is a form of betrayal of the mandate given by the

\footnotetext{
${ }^{7}$ Satjitpo Rahardjo, Biarkan Hukum Mengalir: Catatan kritis tentang Pergulatan Manusia dan Hukum (Jakarta: Kompas, 2007), hlm. 140.

${ }^{8}$ Rahardjo, hlm. 144.
} 
people," Airlangga told IDN Times. Airlangga said the revocation of political rights was a "logical consequence" of the deviation.

The important thing is to build a sense of public confidence in the democratic system. That's the most important. That is, the community believes the list of people who will be elected in the election is morally protected. Secondly, people will see that the act of committing corruption will receive quite severe sanctions, and it is possible for people to think several times to commit acts of corruption, "Airlangga added. ${ }^{9}$

In the past it was said that judges are mouthpieces of the law because their only obligation is to apply the law, it is a subsaattie automaat. ${ }^{10}$ Most of the judges admitted that they still tended to be shackled in making decisions by advancing procedural justice and negating more substantive justice or a sense of justice in the community. ${ }^{11}$

Since corruption is categorized as a serious crime, extraordinary efforts are also needed to fight it. In this case, law enforcement officials must dare to do rule breaking for the achievement of justice? Judges in carrying out their duties must be based on applicable law, the law must be interpreted broadly, not only interpreted as a law, but also includes the law and values that live in society. What really becomes a consequence is that the judge has responsibility for the law, because all law enforcement processes culminate in the court and the judge will determine the law. The law must be a benchmark, as long as the law can provide justice. But if not, the judge can make legal discovery efforts by expanding the meaning and sound of the legislation. ${ }^{12}$

A good decision is one that can reflect a change, the dynamics of community life towards a better or at least the decision can prevent community actors who violate the law so that the decision can be an effective media in

${ }_{9}$ I. D. N. Times dan Rosa Folia, “Pencabutan Hak Politik Warga Negara, Bagaimana Aturannya?," Web Blog, IDN Times, 5 November 2018, https://www.idntimes.com/news/indonesia/rosa-folia/pencabutan-hak-politik-warga-negarabagaimana-aturannya.

${ }^{10}$ Sudikno Mertokusumo, Legal Inventions (an introduction) (Jakarta: Cahaya Atma Pustaka, 2014), hlm. 48.

11 Sulistyowati Irianto, Problems of Judges in the Law, Courts and Society in Indonesia: SocioLegal Studies (Jakarta: Secretariat General of the Judicial Commission of the Republic of Indonesia, 2017), hlm. 188.

12 Darmoko Yudi Witanto dan Arya Putra Negara Kutawaringin, Diskreasi Hakim Sebuah Instrumen Menegakkan Keadilan Substantif Dalam Perkara-perkara Pidana (Bandung: Alpabeta, 2013), hlm. 39. 
creating law order in the community, on a small scale the decision is the media to settle the case being tried, but in a broad sense the consideration of the decision will be polarized into a rule that is generally accepted in society because it contains good values for people's lives.

A criminal verdict will have a deterrent effect if the conviction is worth the crime. This will affect the mental atmosphere of the community at large so as not to do the same thing. ${ }^{13}$ If stakeholders can make policy breakthrough it means that it is tailored to the needs in providing protection and welfare for the community. The attempt to revoke political rights for perpetrators of criminal acts of corruption is interpreted as a step to provide protection to the public from the actions of corruptors.

Although the Constitutional Court's decision in 2009 related to the revocation of the right to be elected in a public position declared to be constitutionally valid by requiring a time limit, it turns out that after the Constitutional Court's decision there were several Judges' decisions revoking the right to be elected in public office by not giving a time limit as stipulated in Article 38 of the Criminal Code in a case:

1) Decision of the Supreme Court of the Republic of Indonesia Number $537 \mathrm{~K} /$ Pid.Sus / 2014 dated June 4, 2014 an. Defendant Inspector General of Police Drs. Djoko Susilo, SH., M.Sc; who decided: Punish the Defendant with additional crimes in the form of revocation of certain rights to vote and be elected in public office.

2) Decision of the Supreme Court of the Republic of Indonesia Number: $1195 \mathrm{~K} /$ Pid.Sus / 2014 dated 15 September 2014 an. The Defendant Lutfi Hasan Ishaaq decided: Revoke the Defendant's right to be elected in a public office.

3) Decision of the Supreme Court of the Republic of Indonesia Number: $1648 \mathrm{~K} /$ Pid.Sus / 2014 dated 17 November 2014 an. Defendant H.M. Rusli Zainal who decided: Determined to revoke the defendant's right to be elected in public office.

4) Decision of the Supreme Court of the Republic of Indonesia Number: $285 \mathrm{~K} /$ Pid.Sus / 2015 dated February 23, 2015 an. Defendant Hj. Ratu Atut Chosiyah, SE who decided: Determined to revoke the defendant's right to be elected in public office.

13 Syaiful Bakhri, Sistem Peradilan Pidana Indonesia: Dalam Perspektif Pembaruan, Teori dan Praktik Peradilan, Cet. I (Yogyakarta: Pustaka Pelajar, 2014), hlm. 224. 
FITRAH Jurnal Kajian Ilmu-ilmu Keislaman

Vol. 05 No. 2 Desember 2019

5) Decision of the Supreme Court of the Republic of Indonesia Number: $1261 \mathrm{~K} /$ Pid.Sus / 2015 dated June 8, 2015 an. Defendant Anas Urbaningrum has decided: To impose an additional sentence against Defendant Anas Urbaningrum in the form of revocation of the right to be elected in public office.

6) Decision of the Supreme Court of the Republic of Indonesia Number: $2864 \mathrm{~K} /$ Pid.sus / 2015 dated January 13, 2016 an. Defendants Ade Swara and Nurlatifah decided: Drop the criminal revocation of the rights of the defendants to be elected in public office.

This is the authority of Judges who adhere to the principle of independence and based on article 5 paragraph (1) of Law number 48 of 2009 concerning judicial power states that judges and constitutional judges are obliged to explore, follow, and understand living legal values and a sense of justice. in society. Thus, the judge can give the decision to revoke the right to be elected in public office for the perpetrators of criminal acts of corruption without time limit due to consideration of legal values and a sense of justice that lives in the community so desires. This is so if the judge does not have progressive optics in solving problems, what happens is that the judge's decision will be dry from a sense of justice for the whole community. Actually the law needs to be interpreted, studied, researched and its practice also requires courage in its support for substantive justice rather than mere formal justice.

Because the Judge can do the legal formation, namely formulating general rules that are generally accepted, for everyone. If legal shaping is usually carried out by lawmakers, judges may also form laws, if the legal findings are then permanent jurisprudence followed by judges and are guidelines for the community, namely decisions containing legal principles formulated in concrete events but gaining force is generally accepted.

So the judge's decision can at the same time contain two elements namely on the one hand the decision is the settlement or resolution of a concrete event and on the other hand is a legal regulation for the future. ${ }^{14}$ The result of the legal discovery by the judge is the law because it has binding power as law because it is stated in the form of a decision. Besides that the legal findings by the

14 Sudikno Mertokusumo, Penemuan Hukum: sebuah pengantar (Malang: Cahaya Atma Pustaka, 2014), hlm. 48. 
judge are a source of law as well. ${ }^{15}$ Demands for justice and certainty, according to Radbruch are fixed parts of the law. Finality contains an element of relativity because the purpose of justice (as the content of the law) is to foster the value of goodness for humans, more as an ethical value in law. ${ }^{16}$

Radbruch constructs his theory based on the basic thesis of the Bavarian school of culture. The essence of the law as a culture of aissenchaft is not a "formal order of norms" as Kelsen's concept. Culture aims to realize values. Hokum as the bearer of the value of justice according to Radbruch is a measure for the unfairness of the legal system. Not only that, the value of justice is also the basis of law as a law. Thus, justice has both a normative and constitutive nature for law. It is normative, because it functions as a transcendental precondition that underlies every dignified positive law. It becomes the moral foundation of the law and at the same time a benchmark for a positive legal system. It is with justice that positive law originates. Justice must be an absolute element of law as a law. Without justice, a rule does not deserve to be legal. ${ }^{17}$

\section{CONCLUSION}

Based on the description above, the authors conclude the following:

1. Penalties in the form of revocation of the right to be elected for public office for perpetrators of criminal acts of corruption have been regulated in the provisions of Article 10 in conjunction with Article 35 in conjunction with Article 38 of the Criminal Code and also in the Decision of the Constitutional Court Number 4 / PUUVII / 2009 dated March 24, 2009 which provides the maximum time limit 5 (five) years.

2. Revocation of the rights chosen for perpetrators of corruption is still urgent to achieve the legal goals of realizing justice and the usefulness of the law to protect the wider social rights of the community. Limiting the length of time for the revocation of the right to be elected in a public office for a maximum of 5 years, it is time to do a correction again keeping in mind the criminal law goals and philosophical objectives of establishing a law on corruption eradication, considering that corruption in Indonesia occurs systematically

${ }^{15}$ Mertokusumo, hlm. 50.

16 Bernard L.Tanya, Teori Hukum, Strategi Tertib Manusia Lintas Ruang dan Ge, Cet. IV (Yogyakarta: Genta Publishing, 2013), hlm. 119.

17 L. Tanya, hlm. 117. 
and extensively so that it does not only harm the country's finances, but also violates the social and economic rights of the community at large, the eradication of corruption needs to be done in an extraordinary way so that it takes courage to punish from law enforcers namely the Public Prosecutor and judge to enforce the law in progressive and responsive ways by providing convictions Revocation of rights is elected in public office or political rights for perpetrators of corruption forever or without time limit through a judge's decision. In addition to being realized in the form of laws and regulations, it can also be realized in the form of judges' decisions which in essence limit the rights of perpetrators of corrupt acts that have harmed state finances. Thus social justice will be desired by the community. The result of the legal discovery by the judge is the law because it has binding power as law because it is stated in the form of a decision. Besides that the legal findings by the judge are a source of law as well. 


\section{REFERENCES}

Amirullah. "4 Eks Napi Korupsi Gugat Peraturan KPU Ke Mahkamah Agung." Web Blog. Tempo, 2018. https://nasional.tempo.co/read/1105127/4-eksnapi-korupsi-gugat-peraturan-kpu-ke-mahkamah-agung.

Bakhri, Syaiful. Sistem Peradilan Pidana Indonesia: Dalam Perspektif Pembaruan, Teori dan Praktik Peradilan. Cet. I. Yogyakarta: Pustaka Pelajar, 2014.

Franz Magnis-Suseno, Corruption Corrupts Indonesia: Notes on Corruption from the Corner of Ethics, quoted in his book Wijayanto \& Ridwan Zachrie, Corruption Corrupts Indonesia, Causes and Effects of Eradication, PT. Gramedia Main Library, 2009

Irawan, Dhani. "Sejak KPK Berdiri, Ada 220 Wakil Rakyat Korup Dijerat." Web Blog. detiknews, 18 September 2018. https://news.detik.com/berita/d4216860/sejak-kpk-berdiri-ada-220-wakil-rakyat-korup-dijerat.

Irianto, Sulistyowati. Problems of Judges in the Law, Courts and Society in Indonesia: Socio-Legal Studies. Jakarta: Secretariat General of the Judicial Commission of the Republic of Indonesia, 2017.

Kristiana, Yudi. Pemberantasan tindak pidana korupsi: perspektif hukum progresif. Jogjakarta: Thafa Media, 2016.

L.Tanya, Bernard. Teori Hukum, Strategi Tertib Manusia Lintas Ruang dan Ge. Cet. IV. Yogyakarta: Genta Publishing, 2013.

Media, Kompas Cyber. “KPK: Hak Politik 26 Koruptor Dicabut Sepanjang 20132017." Web Blog. KOMPAS.com, 26 September 2013. https://nasional.kompas.com/read/2018/09/18/13252541/kpk-hak-politik26-koruptor-dicabut-sepanjang-2013-2017.

Mertokusumo, Sudikno. Legal Inventions (an introduction). Jakarta: Cahaya Atma Pustaka, 2014.

- - - Penemuan Hukum: sebuah pengantar. Malang: Cahaya Atma Pustaka, 2014.

Rahardjo, Satjitpo. Biarkan Hukum Mengalir: Catatan kritis tentang Pergulatan Manusia dan Hukum. Jakarta: Kompas, 2007.

Times, I. D. N., dan Rosa Folia. "Pencabutan Hak Politik Warga Negara, Bagaimana Aturannya?" Web Blog. IDN Times, 5 November 2018. https://www.idntimes.com/news/indonesia/rosa-folia/pencabutan-hakpolitik-warga-negara-bagaimana-aturannya. 
FITRAH Jurnal Kajian Ilmu-ilmu Keislaman

Vol. 05 No. 2 Desember 2019

Witanto, Darmoko Yudi, dan Arya Putra Negara Kutawaringin. Diskreasi Hakim Sebuah Instrumen Menegakkan Keadilan Substantif Dalam Perkara-perkara Pidana. Bandung: Alpabeta, 2013.

\section{Constitution}

Law of the Republic of Indonesia number 31 of 1999 concerning Eradication of Corruption Crimes

Law of the Republic of Indonesia number 20 of 2001 concerning Amendments to Law Number 31 of 1999 concerning Eradication of Corruption

Law number 48 of 2009 concerning Judicial Power

\section{Other sources}

Appeal of Public Prosecutor's Memorandum on behalf of Defendant Anas Urbaningrum, 20 November 2014

Memorandum of Appeals of the Public Prosecutor on behalf of Defendant Anas Urbaningrum, 26 February 2015

Decision of the Supreme Court of the Republic of Indonesia Number: $1261 \mathrm{~K} /$ Pid.Sus / 2015 dated 8 June 2015 on behalf of Defendant Anas Urbaningrum

Decision of the Supreme Court of the Republic of Indonesia Number $537 \mathrm{~K} /$ Pid.Sus / 2014 dated June 4, 2014 on behalf of the Defendant Inspector General of Police Drs. Djoko Susilo, SH., M.Sc

Decision of the Supreme Court of the Republic of Indonesia Number: $1195 \mathrm{~K} /$ Pid.Sus / 2014 dated 15 September 2014 on behalf of Defendant Lutfi Hasan Ishaaq.

Decision of the Supreme Court of the Republic of Indonesia Number: $1648 \mathrm{~K} /$ Pid.Sus / 2014 dated 17 November 2014 on behalf of Defendant H.M. Rusli Zainal.

Decision of the Supreme Court of the Republic of Indonesia Number: $285 \mathrm{~K} /$ Pid.Sus / 2015 dated February 23, 2015 on behalf of Defendant Hj. Ratu Atut Chosiyah, SE. 
Decision of the Supreme Court of the Republic of Indonesia Number: $2864 \mathrm{~K} /$ Pid.sus / 2015 dated January 13, 2016 on behalf of Defendants Ade Swara and Nurlatifah

Decision of the Corruption Court at the Bandung High Court Number 17 / TIPIKOR / 2015 / PT.BDG dated July 9, 2015 on behalf of Defendants Ade Swara and Nurlatifah.

Decision of the Corruption Criminal Court in Bandung District Court Number 126 / Pid.Sus / TPK / 2014 / P.N.Bdg dated 15 April 2015 on behalf of Defendants Ade Swara and Nurlatifah.

Decision of the Constitutional Court number 42 / PUU-XIII / 2015 dated July 9, 2015 on behalf of Petitioner Jumanto

Decision of the Constitutional Court Number 4 / PUUVII / 2009 dated March 24, 2009 on behalf of Petitioner Robertus

Decision of the Supreme Court of the Republic of Indonesia Number 30 P / HUM / 2018 dated September 13, 2018 on behalf of Petitioner Lucianty

Decision of the Supreme Court of the Republic of Indonesia Number 46 P / HUM / 2018 dated September 13, 2018 on behalf of Petitioner Jumanto

Republic of Indonesia Election Commission Regulation Number 26 of 2018 Concerning the

Second Amendment to Election Commission Regulation Number 14 of 2018 Regarding the

Nomination of Election Contestants for Regional Representatives on 6 August 2018

Republic of Indonesia Election Commission Regulation Number 20 of 2018 Regarding the Nomination of Members of the House of Representatives, Provincial Regional House of Representatives, and Regency / City Regional House of Representatives 


\title{
WASTE MANAGEMENT IN UIN SUMATERA UTARA
}

(A TRANSDICIPLINER APPROACH)

\author{
SUKIATI \\ UIN Sumatera Utara \\ Email: sukiatisugiono@uinsu.ac.id \\ DOI: http://dx.doi.org/10.24952/fitrah.v5i2.1951
}

